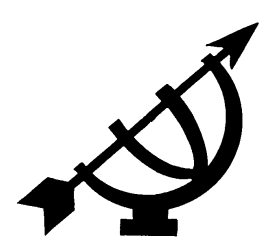

\title{
"A high degree of understanding and tolerance": veranderende denke oor die moderne gereformeerde kerklied
}

\author{
D. Kruger \\ Skool vir Musiek \\ Potchefstroomkampus \\ Noordwes-Universiteit \\ POTCHEFSTROOM \\ E-pos: daleen.kruger@nwu.ac.za
}

\begin{abstract}
"A high degree of understanding and tolerance": changing thoughts on the modern reformed church song

Currently, churches worldwide are experiencing an unparalleled increase in new hymns. Consequently, the requirements of the modern congregational song are much more challenging and demanding. Although the principles of music theory remain a primary criterion for the evaluation of the congregational song, aspects concerning the spiritual requirements, musical taste and culture of the modern church member are becoming increasingly relevant when thinking about the congregational song.
\end{abstract}

In this article the author gives a general overview as to the nature of the modern church song against the background of liturgical renewal within the reformed tradition. The profile of the postmodern church member as regards spiritual needs, musical taste and culture is outlined and connected with the current sensitivity of spirituality and emotional experience through worship and song. Lastly a connection is made between the current trends of hymnological thought and the reformed principles. It is argued that greater tolerance and understanding can lead towards a reforming, rather than a reformed attitude towards the modern congregational song. The discussion is illustrated with examples from the "Liedboek van die kerk" (2001). 


\section{Opsomming}

\section{"A high degree of understanding and tolerance": veranderende denke oor die moderne gereformeerde kerklied ${ }^{1}$}

Wêreldwyd beleef kerke 'n ongekende toename in nuwe kerkliedere en kerkliedstyle. Gevolglik word die vereistes wat aan die moderne kerklied gestel word toenemend uitdagend en veeleisend. Alhoewel die musiekteoretiese beginsels steeds 'n belangrike rol speel, word aspekte soos die behoeftes en musieksmaak van die moderne lidmaat toenemend deel van die moderne denke oor die kerklied.

In hierdie artikel word besin oor die veranderende denke rondom die gereformeerde kerklied. Die outeur beskryf die algemene agtergrond van die moderne kerklied binne die konteks van liturgiese vernuwing en die gereformeerde tradisie. Die profiel van die moderne lidmaat word geskets ten opsigte van kultuur, musieksmaak en spirituele behoeftes en verbind met die hedendaagse sensitiwiteit vir emosionele en spirituele belewenis deur middel van die kerklied. Ten slotte word die verband tussen die hedendaagse himnologiese denke en dié van die Reformasie aangetoon. Die gevolgtrekking waartoe gekom word, is dat akkommoderende denke dit moontlik maak om 'n reformerende eerder as 'n gereformeerde benadering tot die kerklied te kan volg. Die bespreking word toegelig met voorbeelde uit die "Liedboek van die kerk" (2001).

\section{Inleiding}

Gedurende die afgelope vyftig jaar is lidmate van die gereformeerde kerke aan vele veranderings onderwerp (Bell, 1996:5). Op die terrein van die kerkmusiek raak die veranderings veral die ontwikkeling en gebruik van die kerklied en daar is 'n ongekende toename in nuwe kerkliedere. Hierdie kerkliedontploffing (Schalk, 1996:6) is op sigself 'n direkte gevolg van die voortdurende en intense klem wat op liturgiese vernuwing en lofprysing geplaas word (Strydom \& Kellerman, 1992:209; Müller, 1990b:107) en van die toenemende invloed van die charismatiese tradisies op gereformeerde aanbiddingswyses (Brink \& Witvliet, 2003:331).

In die proses van liturgiese vernuwing het die denke oor die kerkmusiek ook ingrypend verander. Dit wil voorkom asof opvattings oor

1 Die outeur betuig graag dank teenoor prof. Hannes van der Walt vir sy waardevolle leiding in die persklaarmaak van hierdie artikel. 
musieksmaak ten opsigte van kerkmusiek tans minder konserwatief, tradisioneel en rigied is as 'n halwe eeu gelede (Studwell, 1996:43). Tog word die tradisionalistiese en modernistiese benaderings nog dikwels teenoor mekaar geplaas wanneer die moderne kerklied ter sprake kom. Dit kon byvoorbeeld bespeur word in die verskillende reaksies op die verskyning van die Liedboek van die kerk (2001). Vir sommige mense was die veranderings "te veel en te gou" en vir ander weer "te min en te laat".

Vanuit 'n postmoderne perspektief dring lidmate toenemend aan op vernuwing en relevansie veral ten opsigte van die liedere wat hulle sing. Die rol wat persoonlike smaak en die kultuur van die lidmaat speel, kan ook nie sonder meer buite rekening gelaat word wanneer oor die kerklied gedink word nie. Die debat oor kerkmusiek word ook dikwels gekenmerk deur die vooropstelling van persoonlike smake en voorkeure en boonop gevoer teen die agtergrond van die grys area van "disagreement between people" (Andrews, 1988:2). 'n Betekenisvolle wending in hierdie debat kan plaasvind indien daar besef word dat alles wat oud is, nie noodwendig sleg en wegdoenbaar is, en alles wat nuut is nie in beginsel altyd goed en bruikbaar is nie (Bell, 1996:7).

Die verskillende ontwikkelings soos hierbo beskryf, dwing kerkmusici (en lidmate) om meer krities met die kerklied om te gaan en nuut daaroor te dink. Vernuwing kan alleen sinvol wees indien dit met omsigtigheid, kundigheid en 'n goeie aanvoeling vir kwaliteit gepaard gaan. Sorgvuldige studie, oorweging en besinning waarby intellektuele eerlikheid en geestelike groei moontlik is (Andrews, 1988:2), sou kenmerkend kan wees van so 'n vernuwende denke oor die kerklied.

In die lig van die voorafgaande, kom die vraag na vore hoe kennis van nuwe denkwyses rondom die aard en funksie van die kerklied kan bydra tot ' $n$ sinvolle implementering van moderne kerkliedere binne die gereformeerde tradisie.

\section{Doelstelling en werkswyse}

In hierdie artikel word ondersoek hoe kennis en begrip van die veranderende denkwyses oor die aard en funksie van die moderne kerklied kan bydra tot 'n sinvolle implementering van nuwe kerkliedere binne die gereformeerde liturgiese tradisie. Ten einde hierdie doelstelling te bereik, word eerstens gekyk na enkele verwikkelings rondom die ontstaan van nuwe kerkliedere. Tweedens word die plasing van die kerklied binne die parameters van die kultuur en 
musieksmaak van die postmoderne lidmaat nagegaan en geëvalueer. Daarna word die profiel van die moderne lidmaat en in die besonder sy/haar instelling teenoor die kerklied en aanbidding ontleed. Ten slotte word lig gewerp op enkele aspekte van eietydse denke, gebaseer op Bybels-reformatoriese perspektiewe, wat kan bydra tot 'n vernuwing in die denke oor die moderne gereformeerde kerklied. Toeligting geskied deur gebruik te maak van voorbeelde uit die Liedboek van die kerk (2001).

\section{Kernbegrippe}

Vir die doel van hierdie artikel is die volgende begrippe van belang: liturgie, gemeente, kerkmusiek en kerklied. Onder liturgie word die organisering van die essensiële elemente van die gereformeerde erediens verstaan, naamlik lofprysing, boetedoening, geloofsbelydenis, prediking, ensovoorts, wat die ontmoeting tussen God en die versamelde gemeente moet reël (Barnard et al., 1991:5). Die gemeente is die vergadering van die gelowiges (Vorster, 1996:47-48). Met kerkmusiek word die totale korpus van musiek wat die kerk in die totaliteit van haar aktiwiteite gebruik bedoel, terwyl die kerklied by uitstek die lied is wat deur die gemeente binne liturgiese verband gesing word (Kruger, 2002: 27).

\section{Die moderne kerklied: algemene agtergrond}

Tydens die Reformasie het bykans 100000 kerkliedere ontstaan en na raming het net ongeveer $9 \%$ hiervan die toets van die tyd deurstaan (Payton,1996:9). Die afgelope vier dekades word 'n soortgelyke kerkliedhervorming of -renaissance beleef (Brink \& Witvliet, 2003: 328). Kerke van alle denominasies word feitlik oorspoel met nuwe melodieë en tekste vir kerkliedere sowel as hersiene of nuutsaamgestelde liedbundels. In 1992 is bereken dat daar tussen 1984 en 1994 in die VSA alleen bykans 40 nuwe kerkliedbundels ontstaan het, waarvan ongeveer 30 vir amptelike gebruik van kerkgenootskappe is (Kloppers, 2003:71).

\subsection{Die kerkliedontploffing}

Schalk (1996:6) verwys na die buitengewone toename in nuwe kerkliedere in alle denominasies as 'n hymn explosion. Binne die gereformeerde verband kan dit onder andere toegeskryf word aan die hernude klem op kollektiewe lofprysing en aanbidding sowel as die vernuwende tendense, veral ten opsigte van die liturgie, in die gereformeerde erediens. 
Debatte oor vernuwing van die liturgie het reeds in die vyftigerjare in die Nederduitse Gereformeerde Kerk (NGK) 'n aanvang geneem (Strydom \& Kellerman, 1992:209). Die uitdrukking van belydenisformulerings in erediensvorme is nie meer as "afgehandel en onaantasbaar beskou nie" en daar is van die standpunt uitgegaan dat die erediens net getrou kan wees aan sy ware aard, indien dit wys in die rigting van die transendente sowel as van die aktuele (Müller, 1990b:107). Hierdie rigtingverandering kan waargeneem word in 'n herlewing van die feestelike en responsoriese karakter van die erediens sowel as die volledige, bewuste en aktiewe deelname (Brink \& Witvliet, 2003:336) van die lidmaat daaraan. Omdat die kerklied, as primêre middel tot gemeentelike deelname aan die erediens, 'n belangrike rol in die proses van liturgiese vernuwing vervul, het daar mettertyd 'n groot behoefte aan nuwe kerkliedere ontstaan.

\subsection{Benaderings tot nuwe kerkliedbundels}

Die toenemende belangstelling in die kreatiewe aanwending van die kerklied het direk neerslag gevind in die samestelling van die toonaangewende liedboeke soos die Psalter Hymnal (1988) en die Complete mission praise (2005). Ook in die Liedboek is gepoog om met die uitbreiding van die kerkliedskat "vir die liturgiese moontlikhede van die lied in die erediens ruimte te skep" en deur middel van 'n "ryk verskeidenheid tekste en melodieë ... dit vir verskillende mense moontlik te maak om die erediens met sang te vul" (Vos, 2001:20).

Kerkleiers en uitgewers van kerksangbundels spits hulle al hoe meer daarop toe om die taal van die kerklied te moderniseer en liedere te veraktualiseer. Daar word op 'n eietydse taalgebruik in die tekste en die toeganklikheid van die melodieë gefokus. Hierdie werkswyses kan byvoorbeeld waargeneem word in 'n vergelyking van die drie omdigtings van Psalm 42 (bekende Geneefse melodie) ${ }^{2}$ en die parafrase daarvan in Lied 163 (eietydse melodie) wat in die Liedboek (2001) opgeneem is: 


\section{Voorbeeld 1:}

- Psalm 42, strofe 1, eerste vier reëls (Totius)

Soos 'n hert in dorre streke / skreeuend dors na die genot / van die helder waterbeke, / skreeu my siel na U, o God!

- Psalm 42, strofe 1, eerste vier reëls (T.T. Cloete) Heer, ek smag na $U$ wat lewe / soos 'n dier na water smag. / Ek wil my na $U$ begewe. / Heer, hoe lank moet ek nog wag?

- Psalm 42, strofe 1, eerste vier reëls (Lina Spies)

Smagtend soos in dorre streke - / hoor my na $U$, Here, roep. / Gee my van u helder water / en 'n skadu teen die gloed.

- Lied 163 (Nystrom, Afrikaanse teks Jan de Wet)

Soos 'n wildsbok wat smag na water, / smag my siel na U, o Heer,

Die talle nuwe liedere is egter nie beperk tot nuwe kerkliedbundels nie. 'n Belangrike aspek in die ontwikkeling van die moderne kerklied het te make met die feit dat kerkliedere dikwels spontaan geskep word, veral deur gebruik te maak van materiaal uit die sfeer van populêre musiek.

\section{3 'n Herlewing van die kontrafaktuurpraktyk}

Die gebruik van melodieë uit die populêre genre by die skepping van nuwe kerkliedere is geen nuwe gebruik in die Protestantse tradisie nie. Dit kan duidelik waargeneem word in Luther se benadering tot die kerklied.

\subsubsection{Historiese praktyk van kontrafakture (contrafacto)}

Die kontrafaktuurpraktyk was byvoorbeeld vir Luther geen vreemde verskynsel nie. 'n Belangrike beweegrede vir sy gebruik van sekulêre melodieë as een van die bronne vir nuwe kerkliedmelodieë, was waarskynlik sy strewe om die "nuwe" gemeentelied so toeganklik as moontlik te maak. Die algemene opvatting van sy tyd was skynbaar dat sulke melodieë deur die Christelike etiek en moraliteit 
van die nuwe tekste verander word en gevolglik hulle "slegte invloede" verloor33 (Wilson-Dickson, 1992:63).

'n Bekende voorbeeld uit die sewentiende-eeuse kontrafaktuurpraktyk is Lied 387 (Liedboek, 2001). Dit was oorspronklik verbind met die sekulêre teks Mein Gmüt ist mir verwirret (1601; Blume, 1974:33). Die bekende geestelike teks 4 waarmee dit tans geassosieer word, is dié van Paul Gerhardt (1647), O Haupt voll Blut und Wunden, wat verwoord is in Lied 387, "O Heer, uit bloed en wonde". Die melodie het dus met verloop van tyd die assosiasie met die oorspronklike sekulêre teks verloor ten gunste van die lydensteks binne die Christelike religie. Dit moet egter hier beklemtoon word dat die aard van dié melodie die geestelike teks se inhoud ondervang en dus as geskikte draer daarvan kan dien.

\subsubsection{Eietydse kontrafakture}

Daar is ' $n$ toenemende tendens in sommige gemeentes van die NGK om ook op hierdie wyse nuwe kerkliedere te skep uit melodiese materiaal wat meestal afkomstig is uit die populêre musiek. 'n Sprekende voorbeeld is Bok van Blerk se kitstreffer De la Rey wat binne weke na die bekendstelling daarvan van 'n godsdienstige teks voorsien is en in sommige kerke gesing word.

Daar word hoofsaaklik op twee maniere te werk gegaan om eietydse kontrafakture te skep. Een praktyk behels dat 'n lied wat enigsins na 'n religieuse onderwerp verwys gou as 'n kerklied aangebied word. Dit kom voor asof mense dink dat wanneer 'n teks 'n illusie van religieusiteit skep, dit die betrokke lied aanvaarbaar maak vir 'n kerklied. Die bekende Battle Hymn of the Republic, ${ }^{5}$ wat reeds wyd inslag gevind het, is 'n goeie voorbeeld van hierdie praktyk.

In 'n ander praktyk word populêre treffermelodieë gebruik as alternatiewe vir bestaande kerkliedmelodieë. Dikwels verdring die alternatiewe melodie baie gou die oorspronklike melodie.

3 Voorwoord: Vierstimmige geistliche Lieder (Frankfurt, 1571), soos aangehaal deur Wilson-Dickson (1992).

$4 \quad$ Verskeie ander tekste het mettertyd ontstaan soos onder andere in Lied 338 en 339.

$5 \quad$ Melodie: William Steffe (1855). 


\section{Voorbeeld 2:}

Sommige gemeentes sing byvoorbeeld Lied 308 op die melodie van The green berets, alhoewel die melodie in die Liedboek ${ }^{6}$ algemeen bekend en toeganklik is. Dit spreek nie vanself dat as die melodie en die teks ewe veel note en lettergrepe het, dit 'n goeie kerklied tot gevolg sal hê nie. Sulke liedere word dikwels deur die meerderheid as "authentic religious music" beskou, maar wat diepgang en trefkrag betref, is dit waarskynlik "unworthy of use" (Hannum, 1969:86). Die probleem met hierdie skeppings is veral geleë in die assosiatiewe kwaliteite7 van die melodieë. Die sterk assosiasie met die populêre kultuur kan maklik tot vervlakking in die uitdrukking van die kerklied lei. Andrews verwys hierna as "one of the most damaging practices today", omdat dit meesal 'n onvanpaste kombinasie van teks en melodie tot gevolg het (soos geïllustreer in hierdie voorbeeld). Hy gaan selfs so ver as om dit te beskryf as een van die "most unholy alliances" in die hedendaagse kerkmusiek (Andrews, 1988:15).

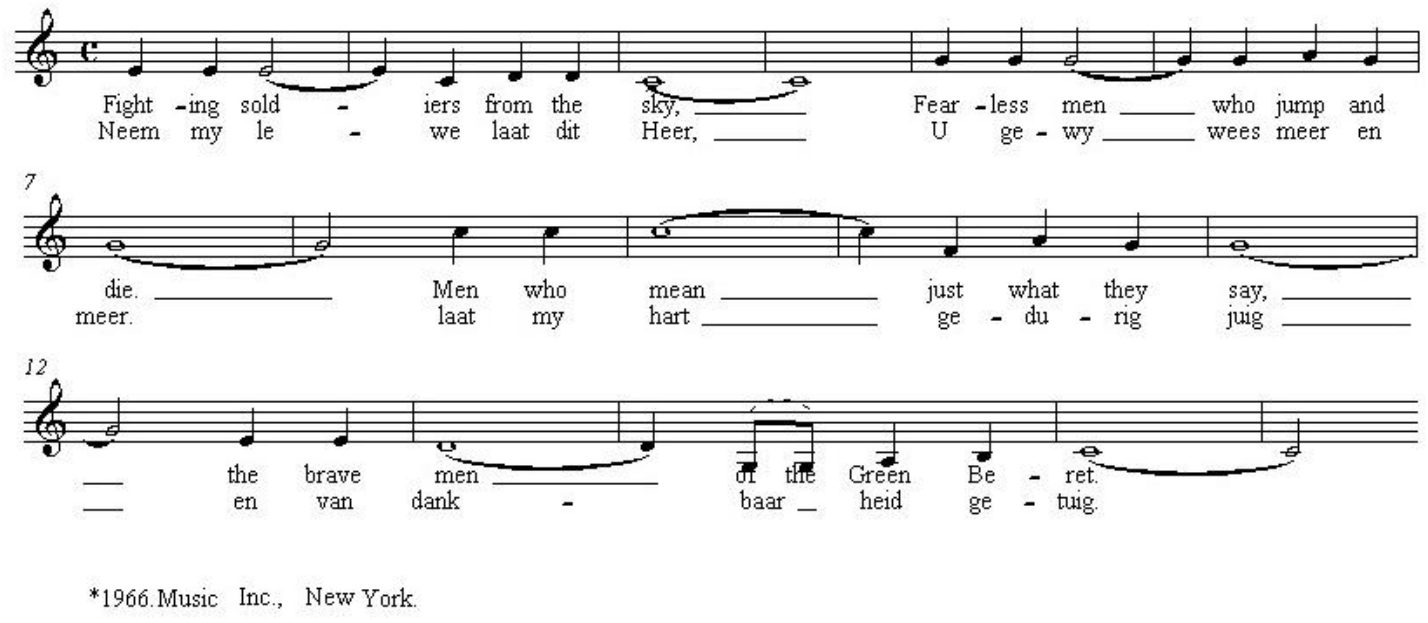

Die vraag ontstaan nou of sekulêre melodieë dan hoegenaamd vir kerkliedere gebruik kan word?

$6 \quad$ Vienna, Justin Knecht (1797).

$7 \quad$ The green berets van Barry Sadler is ' $n$ tipiese voorbeeld van 'n sogenaamde "military occupational folksong" wat tydens die Vietnam-oorlog ontstaan het (Fish, 1989:11). 


\section{Die sekulêre versus die spirituele in die kerklied}

'n Argument wat dikwels in debatte oor die kerklied aangevoer word, is dat die sekulêre teenoor die geestelike/sakrale staan. Johannson (1984:63) argumenteer oortuigend teen die gebruik van die terme sakraal en sekulêr. Hy wys daarop dat waar dit die kerklied aangaan, dit nie bloot handel oor die kwaliteite van dinge (sekulêr of geestelik) nie, maar veral oor die "qualities of relationship orientation". Die verhouding waarin die sogenaamde sakrale en geestelike elemente tot mekaar staan, sowel as die mate waartoe die sekulêre elemente funksioneel binne die liturgiese opset aangewend kan word, word dus beklemtoon.

Ebens (1996:7) voer verder aan dat so 'n afbakening onvanpas is binne die konteks van die Christelike geloof, wat 'n geïntegreerde bestaan verkondig (alles tot eer van God). Johannson se aanbeveling is in hierdie opsig van groot waarde: "Musical choice will not be done according to a sacred-secular category but on music's ability to stand the scrutiny of one's musical theological judgements" (Johannson, 1984:64). Die argumente van Ebens en Johannson plaas die stelling van Schalk (1996:8) dat "[a] successful hymn tune will demonstrate just how far the musical or formal boundaries can be stretched before they break" in 'n ander lig. 'n Soortgelyke benadering word gevolg deur Wolterstorff (1980:185) as hy skryf dat liturgiese sang (dus ook die melodie) in diens staan van die liturgiese aksies en dat die melodieë kan bestaan uit dit "which we find generally good and satisfying to use in this way".

Die gebruik van populêre melodieë in kerkliedere kan vanweë die gewildheid van die melodieë, en in aansluiting by die musieksmaak van die lidmate, 'n sterk sentimentele aantrekkingskrag hê, maar dit verlaag die standaard van die kerklied tot 'n vlak van middelmatigheid wat nie waardig is vir die liturgiese lofprysing nie. Dit sou dus belangrik wees om te verstaan hoe die kerklied binne die parameters van moderne musieksmaak figureer.

\section{Die kerklied en die musieksmaak van die moderne lidmaat}

'n Belangrike aspek in die huidige debat oor die kerklied het te make met die musieksmaak van die moderne lidmaat. In die agtiende en negentiende eeue was daar nie 'n wesenlike onderskeid tussen die algemeen heersende musiekstyl van die tyd en dié van die kerklied nie. Selfs toe kerkliedere vanaf die middel-negentiende eeu, onder sterk invloed van die sogenaamde Herlewingsbewegings (Sanky en 
Moody), algemeen as "expression of religious life" (Austin Phelps, 1860; aangehaal deur Studwell, 1996:37) gesien is, is dit nooit direk met die algemene musieksmaak van die tyd of die gewone samelewing geassosieer nie.

\subsection{Die kerklied en algemene musieksmaak}

Julian (aangehaal deur Studwell, 1996:38) toon aan dat die toename in amptelike en nie-amptelike liedbundels gedurende die negentiende eeu, veral in die Engelssprekende lande, egter daartoe meegewerk het dat kerkliedere al hoe meer gemeet is aan die algemene musieksmaak van diegene wat dit gaan sing. Soos wat die element van "groter byval" algaande belangriker geword het, het daar 'n gaping tussen die aanvanklike "gewyde" sfeer van die kerklied en die algemene musieksmaak van die publiek ontstaan.

Teen die vyftigerjare van die twintigste eeu staan die kerklied reeds in noue verbintenis met die musieksmaak van die gewone mense. Routley (1952) beskryf kerkliedere as "essentially, the people's music". Teen die einde van die twintigste eeu het die kerklied, veral ten opsigte van musiekstyl, van die periferie na die sentrum van algemene musieksmaak verskuif. Die verskuiwing van die algemene smaak (hoofstroom) van die ernstige na die populêre, bring mee dat die opvattings oor musieksmaak ten opsigte van kerkmusiek vandag minder konserwatief, tradisioneel of rigied is as 'n halwe eeu gelede (Studwell, 1996:43.)

Die kerklied word tans ten nouste met massakultuur en die verwagtings van die indiwidu (Studwell,1996:43) verbind. Gevolglik word dit nie meer as elitisties beskou nie en is dit nie vreemd dat die musieksmaak van die indiwidu (wat verteenwoordigend van die algemene smaak is) ook al hoe swaarder weeg wanneer daar oor die kerklied besin word nie.

\subsection{Die kerklied en persoonlike smaak}

Uit bostaande is dit duidelik dat die moderne lidmaat se persoonlike musieksmaak en voorkeure toenemend ' $n$ rol speel by die aanvaarding en/of keuse van 'n kerklied. Die sensitiwiteit vir die algemene musieksmaak het reeds neerslag gevind in die nuutste liedboeke. Die wye verskeidenheid liedgenres en -style wat in die Liedboek opgeneem word, is onder andere tekenend van die poging wat aangewend is om die verskillende musieksmake te bevredig. Liedere in die Liedboek beslaan 'n tydperk van vyf eeue, vanaf die sestiende tot en met die laat twintigste eeu. 
Een van die aspekte van eietydse musieksmaak wat in eietydse kerkliedere manifesteer, is die sterk aanklank by die sentimentele wat onder andere ook verbind kan word met die charismatiese invloed en in besonder die gewildheid van die geestelike luisterlied (gospel song).

Brenner (1989:9) en Payton (1996:7) identifiseer 'n herleefde vorm van piëtisme in sommige moderne kerkliedere. Veral in gebede en liedere met 'n meditatiewe karakter word soms 'n bepaalde sentimentaliteit aangetref. Waar piëtisme (soos in die agtiende eeu) aangewend word om die individuele religieuse lewe te versterk, lei dit in werklikheid tot intellektuele verarming. Piëtistiese liedere gaan dikwels gepaard met vroomheid en 'n groot mate van familiariteit met God. Hierdie elemente kom ondubbelsinnig in sommige eietydse liedere voor, soos byvoorbeeld Lied 518 in die Liedboek. Die "aanvoeling vir die misterie van God" in die erediens word grootliks hierdeur aangetas (Cilliers, 2002:8). In die algemeen kristalliseer die piëtistiese geneigdheid ook uit in 'n sterk emosionele aanslag en belewing en in 'n mate van sentimentalisme in moderne aanbiddingstendense (Brenner, 1989:9).

Nietemin behoort persoonlike artistieke uitdrukking en estetiese goedkeuring nie swaarder te weeg as die feit dat die kerklied in die eerste plek 'n bepaalde liturgiese funksie moet kan vervul nie:

[A] hymn is a good hymn if it serves its purpose effectively and then in addition proves good and satisfying to use for this purpose, that purpose being to enable a congregation to offer praise to God - not be it noted, to give delight upon aesthetic contemplation. (Wolterstorff, 1980:169.)

Dit is ' $n$ feit dat nie al die liedere in 'n liedbundel die smaak van elke lidmaat in die kerk sal kan bevredig nie (Vajda, 1996:185). Die kerklied sal dus 'n middeweg inslaan sodat dit vir die meeste lidmate toeganklik sal wees. Hierdie weg kan moeilik wees "in a society of incredible musical pluralism" (Wolterstorff, 1980:33).

Alhoewel die smaak van die moderne lidmaat dus 'n belangrike rol in die beoordeling van die kerklied speel, sou dit nie gewens wees om besluite te neem bloot op grond van dit waarvan die meerderheid hou nie: "The merit of artistic taste is not dependent upon the number of people who like a particular style" (Hannum, 1969:13). Dickinson (aangehaal deur Hannum, 1969:15) waarsku dat die kerk wat musikale standaarde handhaaf wat laer is as dié van die opgevoede gemeenskap om hom, veral op spirituele vlak, 
nie in eie belang optree nie. Middelmatigheid behoort nie aanvaarbaar te wees nie, maar soos Johannson (1984:53) tereg opmerk, is middelmatigheid meestal die standaard van die populêre smaak en kunsbeoefening.

\section{Die kerklied en kultuur8}

Die verbintenis tussen die kerk(lied) en kultuur is reeds deur Calvyn beklemtoon: "[T]he upbuilding of the church ought to be variously accommodated to the customs of each nation and age" (Brink \& Witvliet, 2003:344). Daar is egter 'n groot verskil tussen kulturele aansluiting en oorgawe (capitulation). Lathrop stel dit soos volg: "[Church] music should be 'in but not of' the culture of the people" (Brink \& Witvliet, 2003:346).

\subsection{Moderne kultuur en die kerklied}

Net soos die sosiokulturele element van kerksang, dus ook die kerklied, nie negeer kan word nie (Müller,1990a:36), kan kultuurbeoefening ook nie van die tydsgees losgemaak word nie. Die postmoderne antroposentriese denkwyse bevraagteken inderdaad ook die aard en effektiwiteit van die kerklied. Die postmoderne mens wil aktief aan die kunste deelneem en dit eg beleef. Die verpopularisering en kommersialisering wat kenmerkend van sommige eietydse kerkliedere is, vorm deel van 'n strategie om kerkmusiek vir die massa toeganklik te maak (Spies, 1998:116).

Hedendaagse kulture word oor die algemeen deur 'n verbruikers- en vermaaklikheidsmentaliteit gekenmerk. Die aandrang op die onmiddellike bevrediging van die deursnee-smaak impliseer dat die laagste gemene deler as maatstaf gebruik word (Spies, 1998:116). Bürger en Huyssen pleit gevolglik vir weerstand teen "easy postmodernism of the 'anything goes' variety" (Spies, 1998:127). Hierdie strominge het 'n besondere sterk uitwerking op die hedendaagse siening van die kerklied. Die vermenging van bekende kerkliedere met populêre melodieë kan as tiperend gesien word van 'n postmodernistiese invloed. Dit sou in die letterkunde vergelyk kon word met Raka die roman deur Koos Kombuis (2005).

$8 \quad$ Hierdie artikel word uit die perspektief van die Westerse kultuur, spesifiek die Afrikaanse gereformeerde milieu geskryf. Die kerkliedere van die Vrye Gereformeerde Kerk en die Gereformeerde Kerk in Afrika val dus buite die raamwerk van hierdie artikel. 


\subsection{Die kerklied: aansluiting by die kultuur}

Routley het reeds in die sestigerjare 'n sterk pleidooi gelewer vir die aansluiting van die kerkmusiek by die kultuur van die gemeente. Hy was van mening dat "a church music is waiting to be born that is relevant to the culture ... which it is our generation's business wholly to admit" (Routley, 1968:106). Aansluiting by die kulturele konteks van die gemeentelede (Johannson, 1984:39) kan bewerkstellig word deurdat die kerklied elemente bevat wat "recognizable and ordinary, both in the composition of the various musical elements and in its total impact" is (Ebens, 1996:6). Hierdie benadering is gevolg in die toonaangewende Psalter Hymnal (1988:13). Elke aanbiddende gemeente moet in staat wees om te kan identifiseer met die reeds bestaande korpus van liedere ten einde nuwe liedere te kan vind tot verryking van hulle begrip van die rykdom van God se koninkryk.

Binne die raamwerk van die "herkenbare" en dit wat aansluiting vind by die kultuur van die gemeente, behoort dit moontlik te wees om "a consensus of musical associations" (Ebens, 1996:6) binne 'n bepaalde kultuurgroep (soos die Afrikaanse gereformeerde kerke) te kan bereik. So ' $n$ tolerante ingesteldheid kan as uitgangspunt gebruik word by die keuse en evaluering van kerkliedere.

Dit blyk dus dat "a high degree of understanding and tolerance" nodig is wanneer daar ' $n$ verbintenis, byvoorbeeld in die erediens, gevorm word tussen mense wat verskillende musieksmake in die kerklied openbaar (Andrews, 1988:11). Binne die konteks van assosiasie kan nie met oortuiging verklaar word watter styl beter of slegter vir die kerklied is nie. In beginsel sou enige styl wat die kerkliedteks oortuigend kan dra, geskik wees vir Christelike aanbidding (Payton,1996:5). Dit sal egter nog steeds onderworpe wees aan die voorkeurstyl van die teikengroep.

\subsection{Die kerklied: aansluiting by die musiekkultuur van die gemeente}

In ooreenstemming met die kultuur en musieksmaak van die gemeente kan 'n musiekstyl geïdentifiseer word wat aansluiting vind by dit wat vir die gemeente "bekend" is. Die algemene musiekstyl (musikale dialek) wat deur die gemeente gebruik word (Pass, 1989:92) behoort dus ook aansluiting te vind by die styl (musikale register) van die kerklied (Kruger, 2002:28).

Die feit dat sommige eietydse melodieë soos byvoorbeeld dié van Vaughan Williams (Lied 441 en 600) en Hubert du Plessis (Lied 261), nie algemeen inslag gevind het by gemeentes nie, hou direk 
verband met musikale dialek en register. Dié melodieë voldoen aan hoë musiekteoretiese vereistes, maar is nie versoenbaar met die algemene musikale dialek van gemeentes nie en die element van vertroudheid ontbreek. Hierdie melodieë kom dus voor as vreemd, hoog of elitisties. Daarteenoor het Lied 269, ook op 'n melodie van Vaughan Williams, wel goeie inslag gevind omdat die strenger klassiektonale benadering, met geen chromatiese verhogings of verlagings nie, makliker versoen kan word met die algemene musikale dialek van die lidmate.

Soortgelyke gevalle word aangetref in van die toonsettings ${ }^{9}$ van Johannes 3:16 wat in die Liedboek opgeneem is: Lied 329 (melodie van Oliviera Hildebrand) en Lied 331 (melodie van Chris Lamprecht). Lied 329 word by voorkeur gesing, waarskynlik omdat dit beter aansluiting vind by die algemene musikale dialek en kultuur van lidmate. Lied 331 is eweneens 'n goeie toonsetting van die teks, maar die langer frases, herhaling van sinsnedes en ingewikkelder melodiese, ritmiese inkleding en harmoniese struktuur maak dit eerder geskik vir die gebruik deur geoefende sangers, byvoorbeeld 'n koor of kantory. In hierdie geval is die musikale register van die lied minder geskik vir lekesangers.

Die gevolgtrekking kan gemaak word dat die seleksie van musiek vir godsdienstige doeleindes nie 'n kwessie van reg en verkeerd (goed of sleg) is nie, maar eerder te make het met kultuur en smaak. Die oogmerk behoort te wees om so ver moontlik liedere te gebruik wat as die beste beskou word in die kultuur waarbinne die gemeente funksioneer (Hannum, 1969:91). In hierdie denkwyse vind eietydse himnoloë opnuut aansluiting by die benadering van die sestiendeeeuse reformatore, wat voorspruit uit die riglyne soos in die Bybel daargestel.

\section{Reformatoriese uitgangspunte ten opsigte van die kerklied}

Die gebruik van Bybelse riglyne in besinnings oor die kerkmusiek staan tereg primêr binne die gereformeerde tradisie en is reeds deur talle outeurs, waaronder Routley (1978), Johannson (1984) en Andrews (1988), in diepte bespreek. Die reformatoriese sienings van Luther en Calvyn wat hieruit voortvloei, word algemeen in debatte rondom die kerklied gebruik.

$9 \quad$ Lied 324 is 'n strofiese weergawe van Johannes 3:16-21. 
Ter fasilitering van hierdie besinning, word enkele uitgangspunte vanuit die gereformeerde tradisie vervolgens bespreek. Hierdie uitgangspunte verskaf 'n belangrike onderbou vir die huidige denke oor die kerklied.

\subsection{Uitgangspunte van die reformatore}

Luther se standpunte oor die gawe en eienskappe van musiek sowel as die voordele daarvan vir liturgiese gebruik, is goed gedokumenteer. Dit is opvallend dat hy die "aardsheid" en "sintuiglikheid" van musiek erken en juis daarin die moontlikheid sien om deur middel van die kerklied aansluiting by die emosionele belewingspektrum van die mens te vind (Strydom, 1994:59).

Calvyn skryf in die Epistre au lecteur (1950 [1543]) dat musiek "the first or one of the principle" gawes is wat God aan die mens gegee het met die doel om homself te kan vernuwe (recreate) en ook om plesier te verskaf. Daarom behoort die mens soveel te meer omsigtig daarmee om te gaan. Calvyn lê ook die eeue oue problematiek van die kerklied duidelik bloot: "For this reason the early doctors of the Church often complain that the people of their time are addicted to dishonest and shameless song ..." (Strunk, 1950: 347). Calvyn waarsku deurgaans teen die negatiewe invloed wat musiek kan hê. Soos Augustinus, skryf hy dat die ore van die lidmate nie op die melodie ingestel moet wees nie, omdat dit die aandag aflei van die teksinhoud. Calvyn vereis dat die klem steeds op die geestelike betekenis van die teks moet lê en die invloed daarvan op die gemoed van die mens (Strydom, 1994:78).

In talle sestiende-eeuse kerkliedere wat in die Lutherse sowel as Calvinistiese kringe ontstaan het, word direkte aansluiting gevind by die eietydse kultuur en musiekstyl. Talle oorspronklike melodieë is gekomponeer, maar daar is ook van reeds bestaande, sekulêre materiaal gebruik gemaak om nuwe kerkliedere te skep. Die moderne denke oor die kerklied, waarin 'n balans tussen emosionele belewing en intellektuele begrip bepleit word, is dus in wese eintlik 'n terugkeer na die ideale wat reeds deur Luther en Calvyn daargestel is. Die waarde wat in die eietydse liturgie aan emosionele belewing geheg word, vind onder andere neerslag in 'n meer spirituele benadering tot aanbidding en die kerklied.

\section{2 'n Spirituele benadering tot die kerklied}

Voortvloeiend uit die gereformeerde siening lewer Andrews (1988:8) 'n geldige pleidooi ten gunste van 'n spirituele benadering tot die 
kerklied. Hy baseer sy uitgangspunt op 1 Korintiërs 2:13-15. Spirituele dinge word deur spiritualiteit onderskei en gevolglik word by die evaluering van die kerklied ook spirituele insig benodig.

\subsubsection{Moderne spiritualiteit}

'n Belangrike kenmerk van die postmoderne mens is sy soeke na 'n nuwe spiritualiteit (Spies, 1998:125). As spiritualiteit verstaan word as die manier waarop die beeld van Christus deur die werking van die Heilige Gees in die lidmaat gestalte kry (Ludik, 2007), kan die aandrang op subjektiewe belewing en ervaring in die erediens (Vorster, 1996:83) ook die kerklied insluit. Vorster (1996:99) is van mening dat die lidmaat homself dus ook in die kerklied moet kan "tuis" voel. Sodoende kan die kerklied en kerksang ook die gewydheid en gees van egte spiritualiteit dien.

Die aspek van subjektiewe belewing is nie net van toepassing op die kerklied nie, maar het veral ook betrekking op die liturgiese inkleding van die erediens. Dit is belangrik dat daar tydens die erediens ' $n$ atmosfeer van aanbidding geskep word. Die kerklied speel ' $n$ belangrike rol, maar sintuiglike en simboliese aspekte het ook ten diepste te make met spiritualiteit (Ware, 1995:5). Dit verklaar die diepe ontroering wat mense tydens die sogenaamde Adoramus-dienste ervaar waar die Taizé-liedere gesing word. Deur middel van kerse, blomme, stiltes, ensovoorts word 'n warm atmosfeer geskep wat sterk aanspraak maak op die sintuiglike belewing van die lidmaat. In hierdie dienste word by uitstek voorsiening gemaak vir 'n diepgaande spirituele belewing - veral in die eenvoud van liedere en gebede wat vir aanbidding gebruik word.

Spiritualiteit is egter 'n begrip met verskeie dimensies. Soos wat lidmate indiwiduele musieksmake het, openbaar hulle ook verskillende spiritualiteitstipes.

\subsubsection{Spiritualiteitstipes}

In die denke oor die ontwikkeling van die moderne kerklied word toenemend rekening gehou met die verskillende spiritualiteitstipes wat lidmate openbaar. Met die ontwikkeling van nuwe kerkliedere word kennis van spiritualiteitstipes met groot vrug aangewend om vir alle lidmate voorsiening te maak (vgl. ook 4.2).

Volgens die vier spiritualiteitstipes wat onderskei word (Ware, 1995: 7), sal lidmate aan verskillende aspekte tydens liturgiese aanbidding waarde heg. Party lidmate sal meer waarde heg aan getuienis en 
musiek (katafaties), ander aan die Woordverkondiging (spekulatief), ensovoorts. Die klassifikasies behoort nie verdelend op die gemeente in te werk nie, maar kan daartoe bydra dat mense mekaar beter verstaan (Ware, 1995:6). Die moderne kerklied in sy verskeidenheid kan baie daartoe bydrae om die onderskeie tipes in 'n gemeente te akkommodeer. Mense wat 'n spekulatiewe spiritualiteit openbaar, sal byvoorbeeld 'n lied verkies wat meer intellektueel van aard is, byvoorbeeld Psalm 42, soos berym deur Cloete, terwyl die beryming van Spies aanklank by die katafatiese lidmaat sal vind. Die affektiewe en apofatiese spiritualiteitstipes sal eerder die verkorte beryming van Lied 163 verkies.

Hoewel die aandag wat aan die lidmaat, sy spiritualiteit en behoeftes geskenk word in die hedendaagse denke al hoe meer op die voorgrond tree, moet die skaal ook gebalanseer word deur die historiese ontwikkeling en erfenis van die kerklied in perspektief te plaas. Soos reeds in afdeling 8.1 aangetoon is, openbaar die resente literatuur oor die algemeen 'n terugkeer na die Bybelse en reformatoriese uitgangspunte. Die agtiende-eeuse denkwyse van Wesley is onlangs weer deur Ebens (1996) uitgelig en veraktualiseer.

\subsection{Wesley se teologiese model}

In sy benadering tot kerkmusiek betrek Ebens (1996:5) die sogenaamde Wesleyaanse vierhoek.10 In John Wesley (1707-1788) se teologiese model vir aanbidding dien die Bybel as vooropgestelde norm, maar met toevoeging van 'n interaktiewe appèl op tradisie, rede en ervaring (Outler, 1991:21). Sy erkenning van die rasionele staan teen die agtergrond van die Christelike tradisie. In kombinasie met mekaar kan hierdie elemente 'n "living spring of Christian insight" teweegbring (Outler, 1991:32-33).

Aan die ander kant misken Wesley nie intuïsie ten koste van die rede nie. Hy sien intuïsie as 'n spiritual sensorium, 'n verbintenis tussen die menslike rede en dit wat kenmerkend menslik is: die (on)vermoë om God te kan verstaan (Outler, 1991:33). Wesley se begrip vir die spirituele en tipies menslike aspekte wat in aanbidding (dus ook in die kerklied) opgesluit is, kan positief verbind word met die opvattings oor spiritualiteit soos dit tans in gereformeerde teologiese denke voorkom. 
Ebens (1996:5) meen dat die vier bene van die sogenaamde Wesleyaanse vierhoek met groot vrug gebruik kan word wanneer daar oor die kerklied besin word. Net soos Wesley deur 'n breër siening van die basiese teologiese formulerings sowel as die gebruik van rede, ervaring en tradisie, sy tydgenote wou aanspoor "to think and let think" (Outler, 1991:25), kan hierdie elemente ook betrek word om die hedendaagse denke oor die kerklied meer akkomoderend te maak: "To sing and let sing". Op hierdie wyse sou 'n progressiewe kombinasie van die oue en die nuwe (vgl. Bell, 1996:7) 'n algemene reformerende benadering tot die kerklied kan bewerkstellig.

\section{4 'n Reformerende benadering tot die kerklied}

Die gereformeerde benadering tot die kerklied was te lank bloot geskoei op teologiese en musiekteoretiese argumente. In hierdie proses is die opgeleide kerkmusikus en die gemeente erg verpolariseer en het die saak van die kerklied groot skade gely. Daar kan tereg gevra word of daar nie te veel klem op die musiek van die Reformasie gelê is nie (byvoorbeeld die Geneefse psalms), ten koste van die reformerende ideale daarvan. Die slagspreuke van die Reformasie, Ecclesia reformata (Kruger, 2002:41) en Semper reformanda (Bell, 1996:11; Perry, 2002:45) sou dus per implikasie ook die voortdurende reformering van die kerklied insluit.

'n Reformerende denkwyse kan gunstig meewerk in die soeke na 'n kerklied wat vir 'n heterogene eietydse gemeente toeganklik sal wees. Dit sou aspekte soos kultuur en musieksmaak sowel as die behoeftes van die moderne lidmaat kon akkommodeer. Sodoende kan die kerklied geanker word binne die demografie van die gemeente: "Hierdie strategie is 'n voorbeeld van die ontsnapping uit 'n abstrakte universaliteit ... na beleefde gemeenskaplikheid" (Spies, 1998:124-125). Dit kan die postmoderne soeke na 'n nuwe spiritualiteit tot voordeel wees.

\section{Slot en samevatting}

Uit die voorafgaande is dit duidelik dat die ontwikkelings rondom die renaissance van die gereformeerde kerklied vereis dat daar nuut oor die aard en wese van die kerklied gedink moet word. Omdat die kerklied al nouer verbind word met die indiwidu wat dit gaan sing, tree die eise en spirituele behoeftes van die postmoderne lidmaat sterk na vore in die nuwe denke oor die kerklied. Die kultuur waarbinne die lidmaat funksioneer, is 'n bepalende faktor in die vorming van algemene musieksmaak. Dit het gevolglik 'n direkte invloed op 
die ontwikkeling en evaluering van nuwe kerkliedere. Die verskynsel van hedendaagse kontrafakture is slegs een manifestasie van die heersende musieksmaak en kultuur in die ontstaan van nuwe kerkliedere.

Te midde van al die ontwikkelings blyk dit dat daar ook 'n hernude beklemtoning is van die Bybels-reformatoriese sienings oor die kerklied. Aansluiting word by nuwe tendense in die teologie en liturgie gevind, soos byvoorbeeld die belangstelling in spiritualiteit en die belewing daarvan in die erediens. Die toepassing van ouer teologiese teorieë in die denke oor die kerklied, soos byvoorbeeld dié van Wesley, kan weer 'n balans bring tussen die oue en die nuwe ten opsigte van die kerklied.

Wanneer al bogenoemde aspekte in ag geneem word, lyk dit asof die moderne denke oor die kerklied, in 'n poging om meer akkommoderend te wees, eerder neig na die reformatiewe. In 'n tyd waarin die algemene opvattings oor die kerkmusiek minder konserwatief is, is dit moontlik vir mense om met meer begrip en verdraagsaamheid oor die kerklied te praat en te dink. Die ongelukkige periode van die sogenaamde worship wars skyn iets van die verlede te wees. Die tyd is ryp vir voortgesette reformerende denke oor die kerklied en die liturgiese aanwending daarvan binne die gereformeerde erediens.

\section{Geraadpleegde bronne}

ANDREWS, V.E. 1988. Considerations for the evaluation of church music: a Biblical approach. Paper presented at the ICTL seminar, Institute for Christian Teaching. Silver Springs: Nebraska Union College.

BARNARD, A.C., VAN DER COLF, A.P. \& MÜLLER, J.C., red. 1991. Handboek vir die erediens. Goodwood: NG Kerk-Uitgewers.

BELL, J. 1996. Reforming worship. Reformed worship, (40):5-11.

BLUME, F. 1974. Protestant church music. New York: Norton.

BRENNER, J.M. 1989. Pietism: past and future. Paper presented at the WELS Michigan District Northern Pastoral Conference. http://www.wls.wels. net/library/Essays/Authors/B/BrennerPietism/Brenner.pdf Date of access: 4 Oct. 2006.

BRINK, E.R. \& WITVLIET, J.D. 2003. Contemporary developments in music in reformed churches worldwide. (In Vischer, L., ed. Christian worship in reformed churches past and present. Michigan: Eerdmans. p. 324-347.)

CALVYN, J. 1950 [1543]. Epistre au Lecteur. Translated by O. Strunk. (In Strunk, O. Source readings in music history. New York: Norton. p. 345348.)

CILLIERS, J. 2002. Die struktuur van die erediens: 'n teologiese perspektief. Vir die musiekleier, 29: 6-11.

COMPLETE MISSION PRAISE. 2005. London: HarperCollins. 
EBENS, A. 1996. Music in worship. http://www.maranathamedia.com.au/ Download?Essays-Sermons/Music\%20in\%20Worship.pdf Date of access: 26 Jan. 2005.

FISH, L. 1989. General Edward G. Landsdale and the folksongs of the Americans in the Vietnam war. Journal of American folklore, 102(406):123. http://facstaff.buffalostate.edu/fish/m/folksong Date of access: 10 Feb. 2005.

HANNUM, H.B. 1969. Music and worship. Nashville: Southern Publishing Association.

JOHANNSON, C.M. 1984. Music and ministry. Massachusetts: Hendrickson.

KLOPPERS, E.C. 2003. Vernuwing in die kerklied: die Liedboek van die kerk (2001). Acta theologica, 1:71-83.

KRUGER, D. 2002. Die funksionaliteit van die laat twintigste-eeuse kerklied. In die Skriflig, 36(1):19-43.

LIEDBOEK VAN DIE KERK. 2001. Wellington: NG Kerk-Uitgewers.

LUDIK, B. 2007. Liturgie inkleding: 'n moderne oogpunt. Referaat gelewer tydens die 27e Algemene Jaarvergadering van die Suid-Afrikaanse Kerkorrelistevereniging, September. (Ongepubliseerd.)

MÜLLER, J. 1990a. Die erediens as fees. Pretoria: NG Kerkboekhandel.

MÜLLER, J. 1990b. Vernuwing in die erediens. (In Smuts, A.J., Vos, C.J.A. \& Nel, M., red. In gesprek oor die erediens: huldigingsbundel aan prof AC Barnard. Pretoria: NG Kerkboekhandel.

OUTLER, A.C. 1991. The Wesleyan theological heritage. Grands Rapids: Zondervan.

PASS, D.B. 1989. Music and the church. Nashville: Broadman.

PAYTON, L. 1996. How shall we sing to God? http://www.sgc.org/musicmin/ HowSing.pdf Date of access: 4 Oct. 2006.

PERRY, G. 2002. Reforming worship. The reformed theological review, 64(10):34-50.

PSALTER HYMNAL. 1988. Grand Rapids: CRC Publishing.

ROUTLEY, E. 1952. Hymns and human life. London: John Murray.

ROUTLEY, E. 1968. Words, music and the church. Nashville: Abingdon.

ROUTLEY, E. 1978. Church music and the Christian faith. London: Collins.

SCHALK, C. 1996. Some thoughts on the writing of hymn tunes. Cross accent, 7:6-10.

SPIES, B.M. 1998. Verrekening van die postmoderne invloed op musiek. Acta academica, 30(1):115-140.

STRUNK, O. 1950. Source readings in music history. New York: Norton.

STRYDOM, W.M.L. 1994. "Sing nuwe sange, nuutgebore": liturgie en lied. Bloemfontein: NG Sendingpers.

STRYDOM, W.M.L. \& KELLERMAN, J.S. 1992. Die funksie van liturgiese sang in gereformeerde erediensvernuwing. Nederduitse Gereformeerde teologiese tydskrif, 24(33):204-215.

STUDWELL, W.E. 1996. The position of the hymn in the cultural spectrum of the late twentieth century. Music reference services quarterly, 5(1):37-44.

VAJDA, J.J. 1996. The making of a hymn. Reformed liturgy and music, 30(4):183-188.

VORSTER, J.M. 1996. Is die kerk aktueel? Potchefstroom: Potchefstroomse Teologiese Publikasies.

VOS, C.J.A. 2001. Liedboek van die kerk. Voorwoord by die liedere. p. 19-20. 
WARE, C. 1995. Discover your spiritual type. New York: Alban University Publications.

WILSON-DICKSON, A. 1992. The story of Christian music. Oxford: Lion.

WOLTERSTORFF, N. 1980. Art in action: toward a Christian aesthetic. Grand Rapids: Eerdmans.

\section{Kernbegrippe:}

gereformeerde kerklied

kontrafaktuurpraktyk

Liedboek van die kerk (2001)

spiritualiteit

\section{Key concepts:}

contrafacta practice

Liedboek van die kerk (2001)

reformed congregational song

spirituality 
